\title{
An Assessment of Vigor and Production of Range Grasses Following Drought
}

\author{
DAVID C. GANSKOPP AND THOMAS E. BEDELL
}

\begin{abstract}
In the growing season following a severe one-year drought in central and eastern Oregon (precipitation $49 \%$ of average), various parameters of individual ungrazed and grazed plants of bluebunch wheatgrass, Idaho fescue, Thurber needlegrass, and crested wheatgrass at 11 locations were evaluated. An average of $43 \%$ aboveaverage precipitation occurred during the study growing season. Lightly grazed Idaho fescue and bluebunch wheatgrass produced as much, and in some cases, more height growth, final weight, and seed stalks than ungrazed plants. No differences occurred between moderately grazed and ungrazed bluebunch wheatgrass and Idaho fescue. Moderately grazed crested wheatgrass produced similarly to ungrazed plants but started growth more slowly. Grazing heavier than $70 \%$ reduced production and height of Idaho fescue and Thurber needlegrass but did not significantly impact bluebunch wheatgrass. No plant mortality occurred regardless of past grazing use.
\end{abstract}

How does past grazing management affect growth of perennial range grasses after drought? This question was addressed following the 1976-77 drought in the Pacific Northwest where precipitation averaged only $49 \%$ of average over much of that area. A number of studies have shown drought caused perennial grass breakup and mortality (Pechanec et al. 1937; Craddock and Forsling 1938; Lang 1945; Blaisdell 1958; Frischknecht and Harris 1968; Sharp 1970; McLean and Van Ryswyk 1973). Drought resistance or tolerance has been related to carbohyd rate accumulation through ability to tolerate high temperatures (Julander 1945). Defoliation by grazing animals also can detrimentally affect plant carbohydrate levels (Mcllvanie 1942; White 1973).

Past grazing history can exert an added influence to that of drought (Stewart 1935; Weaver and Albertson 1936, 1939, 1943; Young 1956; Paulsen and Ares 1961; Herbel et al. 1972). Lightly grazed ranges appear to recover from drought more rapidly than their overgrazed counterparts (Lantow and Flory 1940; Young 1956; Paulsen and Ares 1961). Moderately grazed forage plants were observed to withstand drought better than ungrazed plants (Weaver and Albertson 1936) but heavy use before and during drought will reduce desired plant cover, vigor, and production (Stewart 1935; Weaver and Albertson 1939; Young 1956; Pieper and Donart 1975). During spring-summer, 1978, observations were made on four important perennial grasses to determine the relative recovery after drought as affected by grazing management before and during drought.

\section{Study Areas}

Eleven study sites in central and southeastern Oregon were selected for sampling (Fig. 1). A prerequisite for site selection was a fence line contrast having either an exclosure or ungrazed right of way adjacent to the grazed unit. In each case contrasting units were of equivalent ecological potential. Habitat type, ecological condi-

\footnotetext{
Authors are extension assistant (1977-78) and extension rangeland resources specialist, Orcgon State University, Corvallis, Oregon, respectively.

This article was submitted as Technical Paper No. 5234. Oregon Agricultural Experiment Station, Corvallis.

Manuscript received July 16, 1979.
}

tion of the vegetation, recent grazing use, and precipitation index (\% of long term average) at each location was recorded (Table 1). Habitat types and probable habitat types follow those of Tueller (1962), Daubenmire (1970), Winward (1970), Tisdale (1979), and recent unpublished research in Oregon. Species selected for observation were bluebunch wheatgrass (Agropyron spicatum), crested wheatgrass (Agropyron desertorum), Idaho fescue (Festuca idahoensis), and Thurber needlegrass (Stipa thurberiana). Forage utilization in 1977 was judged to be light if from 0 to $25 \%$, moderate if 25 to $70 \%$, and heavy if exceeding $70 \%$ of plant weight of the species.

\section{Methods}

At each location an exclosure was constructed within the grazed unit to prevent utilization during the 1978 growing season. A paired plant method of sampling was selected to reduce variability. In late fall, 1977, ten individual plants in the grazed area, which appeared to be cropped to the general level of utilization, were selected at random, marked with a numbered stake, and the basal diameter $(\mathrm{mm})$ of each recorded. Ten plants having equivalent diameters were then marked with corresponding numbers in the ungrazed area. Aerial biomass of both grazed and ungrazed plants was removed to crown level. Thus, paired plants were of equivalent basal area and growth form at the beginning of the 1978 growing season.

Plant vigor was monitored using culm height, number of leaves per culm, number of inflorescences per plant, plant yield, and change in plant diameter. These parameters have previously been employed as indicators of plant vigor (Pechanec et al. 1937; Reid and Pickford 1946; Stoddart 1946; Wilson et al. 1966; Mueggler 1970, 1972, 1975; Ratliff and Reppert 1974; Rickard et al. 1975).

Four sampling visits were made to each location following

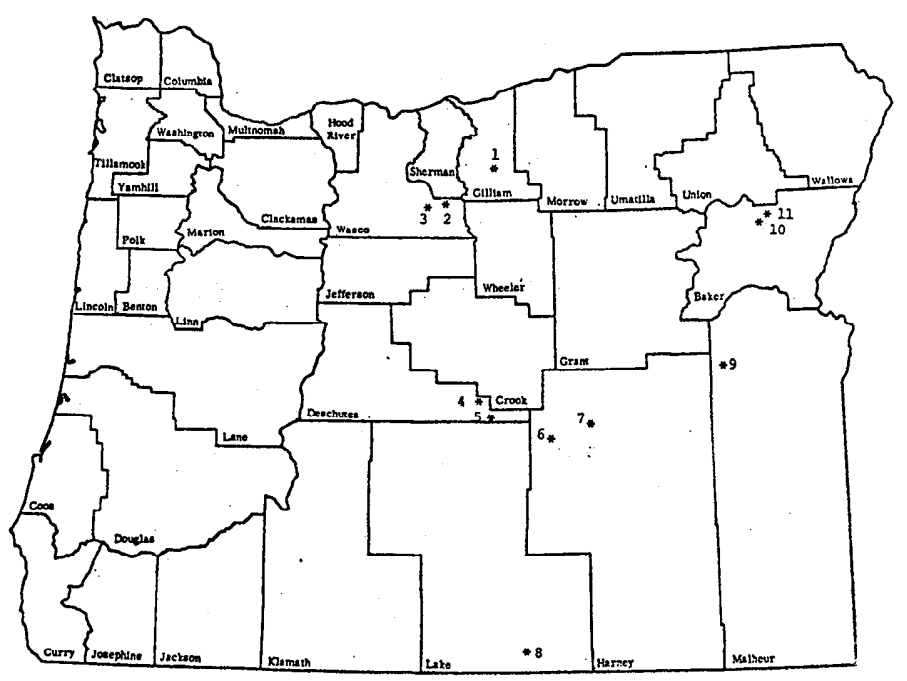

Fig. 1. Location of study areas. 
growth initiation in 1978. Sampling was scheduled as close to the first of each month as possible with each area being visited in April, May, June, and July. At each sampling, extended length of the ten tallest vegetative or reproductive culms of each plant was measured to the nearest $\mathrm{mm}$ and the number of leaves noted. The number of inflorescences per plant was recorded. In July each plant was clipped to crown level, the herbage bagged for later weighing, and plant crown diameters remeasured. Plant samples were oven dried at $50^{\circ} \mathrm{C}$ for $72 \mathrm{~h}$ and weighed to the nearest gram. Basal area per plant was calculated, assuming them to be circular. Both weight and number of seed stalks were adjusted from a per-plant basis to an equal basal area basis. Any observed plant mortality was also quantified in July.

Stem height and leaf count data were averaged on a per plant basis. A paired $t$ test (Steel and Torrie 1960) was employed to analyze significance of differences between the ungrazed and grazed plant parameters for each sampling date.

\section{Results}

Precipitation for the 1978 crop year (September 1, 1977-June 30,1978 ) averaged $143 \%$ of average (Table 1) ranging from 107 to $171 \%$ at the sampling locations. Above-average temperatures during early spring contributed to abnormally good growing conditions. Soil moisture appeared to remain adequate for plant growth through mid-July. No significant plant mortality or clone disintegration was observed at any site that could be ascribed to drought or grazing. Thorough searching yielded an occasional dead plant in ungrazed areas. However, rodent disturbances were believed to be the cause of death in each instance.

\section{Idaho fescue}

Seasonal height growth of Idaho fescue lightly grazed in 1977 was equal to or greater than plants not previously grazed (Table 2 ). At location 2 the height difference was especially pronounced. Plant weight and numbers of seed stalks on grazed plants signifi- cantly exceeded those of ungrazed plants $(p<0.10)$. At location 6 grazed height growth significantly exceeded $(p<0.05$ and 0.01$)$ that of ungrazed plants in June and July. Weights and seed stalk numbers of grazed plants were 34 and $72 \%$ greater, respectively, than those of the ungrazed plants $(p<0.10)$. No height, weight, or seed stalk number differences occurred between lightly grazed and ungrazed Idaho fescue at location 7.

Moderate grazing affected height and weight similarly at the two study locations (Table 2) although height growth of ungrazed plants was significantly greater $(p<0.10)$ at location 3 in April and May. More seed stalks developed on grazed plants than ungrazed plants at location $3(p<0.10)$.

Height growth of heavily grazed Idaho fescue, however, was less early in the sampling period and remained so until the June sampling date (Table 2). Weight of ungrazed plants significantly $(p<0.05)$ exceeded that of grazed plants but seed stalk numbers were not different. Crop year precipitation was $159 \%$ of average at location 4.

\section{Bluebunch Wheatgrass}

Seasonal height growth of lightly grazed bluebunch wheatgrass significantly exceeded $(p<0.01)$ that of ungrazed plants at locations 2 and 6 (Table 3). Plant weight differences were significant $(p<0.10)$ at both locations. Greater growth, weight, and seed stalk numbers at location 2 compared to location 6 is a reflection of ecological site, condition, and seasonal precipitation. Location 2 received $137 \%$ of average precipitation as compared to location 6 with $106 \%$.

Both moderate and heavy grazing of bluebunch wheatgrass had no significant effect on seasonal height growth, weight, and seed stalk numbers (Table 3 ) as compared to ungrazed plants. Although precipitation was 37 and 50\% above average for locations $I$ and 9, inherent site dryness (bluebunch wheatgrass/Sandberg blucgrass and Wyoming sagebrush/bluebunch wheatgrass) appeared to control the time of growth cessation to mid-June.

Table 1. Habitat type, ecological condition, recent grazing use, and crop year (September 1-June 30) precipitation index at each study location.

\begin{tabular}{|c|c|c|c|c|c|c|}
\hline \multirow[b]{2}{*}{ Location } & \multirow[b]{2}{*}{ Habitat type ${ }^{1}$} & \multicolumn{2}{|c|}{ Ecological condition } & \multirow[b]{2}{*}{ Recent grazing use } & \multicolumn{2}{|c|}{ Precipitation index $(\%)$} \\
\hline & & Ungrazed & Grazed & & 1977 & 1978 \\
\hline 1 & $\begin{array}{l}\text { Agropyron spicatum/Poa } \\
\text { sandbergii }\end{array}$ & High seral & High seral & Moderate, fall & 60 & 137 \\
\hline 2 & $\begin{array}{l}\text { Agropyron spicatum-Festuca } \\
\text { idahoensis }\end{array}$ & Climax & Climax & Light, fall & 47 & 137 \\
\hline 3 & $\begin{array}{l}\text { Festuca idahoensis-Agropyron } \\
\text { spicatum }\end{array}$ & High seral & High seral & Moderate, spring \& fall & 47 & 137 \\
\hline 4 & $\begin{array}{l}\text { Artemisia tridentata subsp. } \\
\text { vaseyana/Festuca idahoensis }\end{array}$ & Mid seral & Low seral & Heavy, spring \& fall & 83 & 159 \\
\hline 5 & $\begin{array}{l}\text { Artemisia tridentata subsp. } \\
\text { wyomingensis/Stipa thurberiana }\end{array}$ & Seeded & Seeded & Moderate, spring \& fall & 83 & 159 \\
\hline 6 & $\begin{array}{l}\text { Artemisia arbuscula/Festuca } \\
\text { idahoensis }\end{array}$ & High seral & High seral & Light, spring \& fall & 59 & 106 \\
\hline 7 & $\begin{array}{l}\text { Artemisia tridentata subsp. } \\
\text { tridentata/Festuca idahoensis }\end{array}$ & High seral & High seral & Light, spring & 44 & 134 \\
\hline 8 & $\begin{array}{l}\text { Artemisia tridentata subsp. } \\
\text { vaseyana/Stipa thurberiana }\end{array}$ & High seral & Mid seral & Heavy, summer & 49 & 171 \\
\hline 9 & $\begin{array}{l}\text { Artemisia tridentata subsp. } \\
\text { wyomingensis/Agropyron } \\
\text { spicatum }\end{array}$ & High seral & Mid seral & Heavy, summer \& fall & 55 & 150 \\
\hline 10 & $\begin{array}{l}\text { Artemisia tridentata subsp. } \\
\text { wyomingensis/Festuca idahoensis }\end{array}$ & High seral & Mid seral & Moderate, summer & 49 & 150 \\
\hline 11 & $\begin{array}{l}\text { Artemisia tridentata subsp. } \\
\text { wyomingensis/Agropyron } \\
\text { spicatum }\end{array}$ & Seeded & Seeded & Moderate, spring & 49 & 150 \\
\hline
\end{tabular}

'Habitat types and probable habitat types are of Daubenmire (1970), Tisdale (1979), Tueller (1962), Winward (1970) and recent unpublished research in Oregon. 
Table 2. Seasonal average culm height, final weight, and number of reproductive culms adjusted to equivalent basal area of Idaho fescue in 1978.

\begin{tabular}{|c|c|c|c|c|c|c|c|}
\hline \multirow[b]{2}{*}{ Location } & \multirow[b]{2}{*}{ Grazing } & \multicolumn{4}{|c|}{ Height $(\mathrm{mm})$} & \multirow{2}{*}{$\begin{array}{l}\text { Weight } \\
\mathrm{g} / \mathrm{dm}^{2}\end{array}$} & \multirow{2}{*}{$\begin{array}{l}\text { Seed stalks } \\
\text { No. } / \mathrm{dm}^{2}\end{array}$} \\
\hline & & April & May & June & July & & \\
\hline \multirow[t]{2}{*}{2} & None & 184 & 212 & 441 & 456 & 10.7 & 58 \\
\hline & Light fall & 183 & $283^{* * * 1}$ & $641^{* * *}$ & $660 * * *$ & $27.1^{*}$ & $104^{*}$ \\
\hline \multirow[t]{2}{*}{6} & None & 135 & 156 & 301 & 375 & 10.7 & 54 \\
\hline & Summer-fall & 125 & 153 & $395^{* *}$ & $533 * * *$ & $14.4^{*}$ & $93^{*}$ \\
\hline \multirow[t]{2}{*}{7} & None & 165 & 202 & 435 & 528 & 13.0 & 57 \\
\hline & Light spring & 159 & 202 & 461 & 564 & 13.0 & 73 \\
\hline \multirow[t]{2}{*}{3} & None & $186^{*}$ & $244 * *$ & 524 & 603 & 37.2 & 12 \\
\hline & $\begin{array}{l}\text { Moderate } \\
\text { summer-tall }\end{array}$ & 162 & 212 & 523 & 625 & 49.1 & $21^{*}$ \\
\hline \multirow[t]{2}{*}{10} & None & 198 & 259 & 626 & 629 & 18.4 & 63 \\
\hline & Moderate summer & 170 & 256 & 639 & 648 & 19.7 & 47 \\
\hline \multirow[t]{2}{*}{4} & None & $100^{* * *}$ & $134^{* * *}$ & 230 & 370 & $12.2^{* *}$ & 32 \\
\hline & $\begin{array}{l}\text { Heavy } \\
\text { spring-fall }\end{array}$ & 71 & 98 & 199 & 371 & 7.4 & 27 \\
\hline
\end{tabular}

1*, ${ }^{* *},{ }^{* * *}$ Differences between no grazing and grazing $p<0.10, p<0.05, p<0.01$.

\section{Crested Wheatgrass}

The pattern of seasonal height growth of moderately grazed crested wheatgrass reacted differently between locations 5 and 11 (Table 4). At location 5, a Wyoming sagebrush/Thurber needlegrass habitat type which stayed cold into late May, height of ungrazed plants significantly excceded grazed plants throughout the growing season $(p<0.05)$. Neither final plant weight nor seed stalk numbers were different for grazed versus ungrazed plants at location 5. Early season height of ungrazed crested wheatgrass was significantly greater than that moderately grazed at location 11 , a Wyoming sagebrush/bluebunch wheatgrass habitat type $(p<0.05)$. But, grazed plants grew more than ungrazed during May and June $(p<0.05)$ (Table 4$)$. Grazed plants produced significantly more seed stalks $(p<0.01)$ but not significantly more weight at location 11.

\section{Thurber Needlegrass}

Seasonal heights, final weight and numbers of seed stalks of ungrazed plants were greater than heavily grazed plants of Thurber needlegrass (Table 5). The difference in height was most evident in July as compared to June. Precipitation was over $170 \%$ of average at this location and soil moisture was still adequate for some growth in early July.

\section{Discussion}

The lack of significant mortality or clone disintegration in the species examined indicated that there was little if any bunchgrass deterioration which could be related specifically to the 1976-77 drought. Pechanec et al. (1937) noted that the 1934 Idaho drought was preceded by 12 years of subnormal precipitation. Thus, much of the drought-caused range deterioration reported by these and other researchers (Stewart 1935; Craddock and Forsling 1938) was the result of a predisposing series of low precipitation years followed by what was called a severe, one-year drought. Blaisdell
(1958) reported very poor correlations between basal area and annual precipitation. Probably bunchgrass basal area in the Pacific Northwest is more closely related to climatic cycles than annual precipitation.

The effects of drought on these grasses were not possible to assess since no predrought measurements were made for comparison. Effects of grazing intensity could be determined. This distinction between effects of drought and effects of grazing is difficult to draw except by implication. The observations and evidence set forth here suggested that one-year's drought, although seriously reducing plant growth and thus available forage, did not have as much effect on these grasses as had previous levels of grazing.

Growth of grasses grazed previous to 1978 as compared to ungrazed grasses reflected effects of grazing intensity. For both Idaho fescue and bluebunch wheatgrass light grazing resulted in faster and more height growth and at least as much weight and numbers of seed stalks than comparable plants not grazed for several years. Much the same inference could be made regarding moderate grazing of the two species. Grazing by opening up a bunchgrass crown can result in more physiologically youthful plants where more favorable temperature and light relationships occur (Dahl and Hyder 1977).

Heavy grazing intensities reduced growth of Thurber needlegrass and Idaho fescue but not bluebunch wheatgrass in this study. At only three of 11 locations was heavy grazing observed. For Idaho fescue and Thurber needlegrass some reduction in early season height growth occurred and with Thurber needlegrass a reduction in late season growth as well. The height difference during June and July between ungrazed and heavily grazed Thurber needlegrass at a time when adequate soil moisture was still available suggests that the grazed plants had a more shallow and perhaps less vigorous root system. One season's protection of heavily grazed Idaho fescue did allow similar June and July heights

Table 3. Seasonal average culm height, final weight, and number of reproductive culms adjusted to equivalent basal area of bluebunch wheatgrass in 1978.

\begin{tabular}{|c|c|c|c|c|c|c|c|}
\hline \multirow[b]{2}{*}{ Location } & \multirow[b]{2}{*}{ Grazing } & \multirow[b]{2}{*}{ April } & \multicolumn{3}{|c|}{ Height $(\mathrm{mm})$} & \multirow{2}{*}{$\begin{array}{l}\text { Weight } \\
\text { No. } / \mathrm{dm}^{2}\end{array}$} & \multirow{2}{*}{$\begin{array}{l}\text { Seed stalks } \\
\mathrm{g} / \mathrm{dm}^{2}\end{array}$} \\
\hline & & & May & June & July & & \\
\hline \multirow[t]{2}{*}{2} & None & 264 & 331 & 636 & 645 & 18.1 & 45 \\
\hline & Light fall & 274 & $393 * * * 1$ & $716^{* *}$ & $708 *$ & $23.2^{*}$ & 50 \\
\hline \multirow[t]{2}{*}{6} & None & 166 & 198 & 344 & 431 & 5.0 & 7 \\
\hline & Light summer-fall & 173 & 224 & $419^{* * *}$ & 516 & $8.5^{*}$ & 15 \\
\hline \multirow[t]{2}{*}{12} & None & 262 & 363 & 598 & 599 & 2.5 & 230 \\
\hline & Moderate fall & 249 & 349 & 583 & 569 & 2.9 & 300 \\
\hline \multirow[t]{2}{*}{9} & None & 229 & 312 & 573 & 581 & 11.0 & 10 \\
\hline & Heavy summer-fall & 209 & 286 & 555 & 577 & 14.5 & 12 \\
\hline
\end{tabular}

$1 *, * *, * *$ Differences between no grazing and grazing $p<0.10, p<0.05, p<0.01$.

${ }^{2}$ Failure to record end of growing season plant diameters required that weight (grams) and number of seed stalks be expressed on a per plant basis. 
Table 4. Seasonal average culm height, final weight and number of reproductive culms adjusted to equivalent basal area of crested wheatgrass in 1978.

\begin{tabular}{|c|c|c|c|c|c|c|c|}
\hline \multirow[b]{2}{*}{ Location } & \multirow[b]{2}{*}{ Grazing } & \multicolumn{4}{|c|}{ Height (mm) } & \multirow{2}{*}{$\begin{array}{l}\text { Weight } \\
\mathrm{g} / \mathrm{dm}^{2}\end{array}$} & \multirow{2}{*}{$\begin{array}{l}\text { Seed stalks } \\
\text { No. } / \mathrm{dm}^{2}\end{array}$} \\
\hline & & April & May & June & July & & \\
\hline \multirow[t]{2}{*}{5} & None & $230^{* * * 1}$ & $260^{* * * *}$ & $374^{* * *}$ & $438^{*}$ & 21.2 & 16 \\
\hline & Moderate spring \& fall & 112 & 160 & 296 & 385 & 22.7 & 35 \\
\hline \multirow[t]{2}{*}{11} & None & $167^{* *}$ & 231 & 551 & 690 & 20.8 & 14 \\
\hline & Moderate spring & 118 & 203 & $614^{* *}$ & 740 & 27.3 & $38^{* *}$ \\
\hline
\end{tabular}

${ }^{1 *},{ }^{* *},{ }^{* * *}$ Differences between no grazing and grazing $p<0.10, p<0.05, p<0.01$.

Table 5. Seasonal average culm height, final weight and number of reproductive culms adjusted to equivalent basal area of Thurber needlegrass in 1978.

\begin{tabular}{|c|c|c|c|c|c|c|c|}
\hline \multirow[b]{2}{*}{ Location } & \multirow[b]{2}{*}{ Grazing } & \multicolumn{4}{|c|}{ Height (mm) } & \multirow{2}{*}{$\begin{array}{l}\text { Weight } \\
\mathrm{g} / \mathrm{dm}^{2}\end{array}$} & \multirow{2}{*}{$\begin{array}{l}\text { Seed stalks } \\
\text { No. } / \mathrm{dm}^{2}\end{array}$} \\
\hline & & April & May & June & July & & \\
\hline 8 & $\begin{array}{l}\text { None } \\
\text { Heavy summer }\end{array}$ & $\begin{array}{l}191 * 1 \\
146\end{array}$ & $\begin{array}{l}258^{* *} \\
206\end{array}$ & $\begin{array}{l}476^{*} \\
387\end{array}$ & $\begin{array}{l}584^{* *} \\
426\end{array}$ & $\begin{array}{l}13.9 \\
11.7\end{array}$ & $\begin{array}{l}58 \\
35\end{array}$ \\
\hline
\end{tabular}

${ }^{1 *},{ }^{* *},{ }^{* * *}$ Differences between no grazing and grazing $p<0.10, p<0.05, p<0.01$.

and numbers of seed stalks but significantly more weight per plant was noted for ungrazed plants.

Bluebunch wheatgrass exhibited essentially the same growth responses whether heavily or moderately grazed. The ecological site on which the bluebunch wheatgrass occurred (Wyoming sagebrush/bluebunch wheatgrass) was considerably different than those where the other heavily grazed species were studied (mountain sagebrush/Idaho fescue and mountain sagebrush/Thurber needlegrass). Since grazing histories also were different, one cannot conclude that bluebunch wheatgrass is less susceptible to heavy use than Thurber needlegrass and Idaho fescue. Mueggler (1975) showed that bluebunch wheatgrass was not only more sensitive to clipping but recovered more slowly than Idaho fescue when both were on the same site. The site at location 9 warmed sooner in 1978 than locations 4 and 8 , which could have aided the heavily grazed bluebunch wheatgrass plants.

Results with moderately grazed crested wheatgrass at the two locations were different except for plant weights. Crested wheatgrass makes early root growth and exhibits carly carbohydratc accumulation, so moderate early grazing would not be expected to reduce yield and apparent vigor (Hyder and Sneva 1959; Trlica and Cook 1972). Although ecological differences do occur between locations 5 and 11 , the difference in 1978 height growth pattern may result from immediate past grazing history. Both stands were stocked at approximately 5.5 acres per animal unit month but that at location 5 was fall 1977 grazed and that at location 11 spring grazed. Spring temperatures in 1978 at location 5 were also cooler than at location 11. Consequently, grazed plants at location 5 could have been subjected to more microenvironmental stress during the early part of the growing season.

Because the 1978 growing season was abnormally wet following an extremely dry year, grass growth also can be considered to have been above normal. The extent to which such growing conditions masked grazing intensity effects can only be conjecture. Grazing effects might have been more striking if the year following the drought had been closer to normal. With innumerable studies over many years showing that moderate grazing intensities do not result in resource damage (Nelson 1934; Weaver and Albertson 1936, 1939; Lantow and Flory 1940; Young 1956; Paulsen and Ares 1961), we believe that the results under average growing conditions would not be much different from these.

\section{Literature Cited}

Blaisdell, J.T. 1958. Seasonal development and yield of native plants on the upper Snake River Plains and their relation to certain climatic factors. U.S. Dep. Agr. Tech. Bull. 1190.68 p.

Craddock, G.W., and C.L. Forsling. 1938. The influence of climate and grazing on spring-fall sheep range in southern Idaho. U.S. Dep. Agr.
Tech. Bull. 600. 43 p.

Dahl, B.E., and D.N. Hyder. 1977. Developmental morphology and management implications. In: R.E. Sosebee (ed.) Rangeland Plant Physiology. Soc. Range Manage. Range Science Series No. 4.

Daubenmire, R. 1970. Steppe vegetation of Washington. Washington Agr. Exp. Sta. Tech. Bull. 62. 131 p.

Frischknecht, N.C., and L.E. Harris. 1968. Grazing intensities and systems on crested wheatgrass in central Utah: Response of vegetation and cattle. U.S. Dep. Agr. Tech. Bull. 1388. 47 p.

Herbel, C.H., F.N. Ares, and R.A. Wright. 1972. Drought effects on semi-desert grassland range. Ecology 53:1084-1093.

Hyder, D.N., and F.A. Sneva. 1959. Growth and carbohydrate trends in crested wheatgrass. J. Range Manage. 12:271-276.

Julander, 0. 1945. Drought resistance in range and pasture grasses. Plant Physiol. 20:573-599.

Lang, R. 1945. Density changes of native vegetation in relation to precipitation. Wyoming Agr. Exp. Sta. Bull. 272. 31 p.

Lantow, J.L., and E.L. Flory. 1940. Fluctuating forage production: Its significance in proper range and livestock management on southwestern ranges. Soil Conserv. 6:137-144.

McIlvanie, S.K. 1942. Carbohydrate and nitrogen trends in bluebunch wheatgrass (Agropyron spicatum) with special reference to grazing influences. Plant Physiol. 17:540-547.

McLean, A., and A.L. Van Ryswyk. 1973. Mortality in crested wheatgrass and Russian wildrye. J. Range Manage. 26:431-433.

Mueggler, W.F. 1970. Influence of competition on the response of Idaho fescue to clipping. U.S. Dep. Agr. Forest Serv. Res. Pap. INT-73. 10 p.

Mueggler, W.F. 1972. Influence of competition on the response of bluebunch wheatgrass to clipping. J. Range Manage. 25:88-92.

Mueggler, W.F. 1975. Rate and pattern of vigor recovery in Idaho fescue and bluebunch wheatgrass. J. Range Manage. 28:198-204.

Nelson, E.W. 1934. The influence of precipitation and grazing upon black grama grass range. U.S. Dep. Agr. Tech. Bull. 409. 32 p.

Paulson, H.A., Jr., and F.N. Ares. 1961. Trends and carrying capacity and vegetation on an arid southwestern range. J. Range Manage. 14:78-83.

Pechanec, J.F., G.D. Pickford, and G. Stewart. 1937. Effect of the 1934 drought on native vegetation of the upper Snake River Plain of northern Idaho. Ecology 18:490-505.

Pieper, R.D., and G.B. Donart. 1975. Drought and southwestern range vegetation. Rangeman's J. 2:176-178.

Ratliff, R.D., and J.N. Reppert. 1974. Vigor of Idaho fescue grazed under rest rotation and continuous grazing. J. Range Manage. 27:447-449.

Reid, E.H., and G.D. Pickford. 1946. Judging mountain meadow range conditon in eastern Oregon and eastern Washington. U.S. Dep. Agr. Circular No. 748. $31 \mathrm{p}$.

Rickard, W.H., D.H. Uresk, and J.F. Cline. 1975. Impact of cattle grazing on three perennial grasses in south central Washington. J. Range Manage. 109-112.

Sharp, L.A. 1970. Suggested management programs for grazing crested wheatgrass. Univ. of Idaho Forest Wildl. and Range Exp. Sta. Bull. 4.19 p.

Steel, R.G.D., and J.H. Torrie. 1960. Principles and Procedures of Statistics. McGraw Hill, New York. 481 p. 
Stewart, G. 1935. Plant cover and forage conditions on spring-fall and winter ranges largely on public domain lands in the intermountain region. Utah State Agriculture College. Utah Juniper 6:9-13.

Stoddart, L.A. 1946. Some physical and chemical responses of Agropyron spicatum to herbage removal at various seasons. Utah Agr. Exp. Sta. Bull. 324. 24 p.

Tisdale, E.W. 1979. A preliminary classification of Snake River Canyon grasslands in Idaho. Univ. of Idaho. Univ. of Idaho Forest Wildl. and Range Exp. Sta. Note 32.8 p.

Trlica, M.J., Jr., and C.W. Cook. 1972. Carbohydrate reserves of crested wheatgrass and Russian wildrye as influenced by development and defoliation. J. Range Manage. 25:430-435.

Tueller, P.T. 1962. Plant succession on two Artemisia habitat types in southeastern Oregon. PhD diss. Oregon State Univ., Corvallis. 249 p.
Weaver, J.E., and F.W. Albertson. 1936. Effects of the great drought on the prairies of Iowa, Nebraska and Kansas. Ecology. 17:567-639.

Weaver, J.E., and F.W. Albertson. 1939. Major changes in grassland as a result of continued drought. Bot. Gaz. 100:576-591.

Weaver, J.E., and F.W. Albertson. 1943. Resurvey of grasses, forbs and underground plant parts at the end of the great drought. Ecol. Monog. 13:64-117.

White, L.M. 1973. Carbohydrate reserves of grasses: A review. J. Range Manage. 26:13-18.

Wilson, A.M., G.A. Harris, and D.H. Gates. 1966. Cumulative effect of clipping on yield of bluebunch wheatgrass. J. Range Manage. 19:90-91.

Winward, A.H. 1970. Taxonomic and ecological relationships of the big sagebrush complex in Idaho. PhD diss. Univ. of Idaho, Moscow. 80 p.

Young, V.A. 1956. The effect of the 1949-1954 drought on the ranges of Texas. J. Range Manage. 9:139-142. 